\title{
CEO Turnover and Equity Volatility
}

\author{
Hui $\mathrm{Li}^{*}$ and Paul Farah
}

La Trobe University, Australia.

\begin{abstract}
Purpose of the paper: This study aims to investigate changes in equity volatility around CEO turnovers. It proposes hypotheses regarding the impact of CEO performance and types of turnover on the changes in equity volatility. It extends the current understanding of the existing theories by providing new empirical evidence.
\end{abstract}

Design/methodology/approach: This paper uses both event study and regression analysis to examine and test the hypotheses proposed empirically. Data are obtained from multiple databases.

Findings: This study finds evidence that the relationship between changes in equity volatility and the likelihood of CEO turnovers does not monotonically increase, but is a function of the various types of turnovers and successions. Compared to the departure of outperforming CEOs, the change in equity volatility following the departure of underperforming CEOs is much greater. The positive relationship between the change in volatility and past underperformance is stronger for forced turnovers than for voluntary turnovers. Equity volatility is substantially lower when the CEO relinquishing the post remains as an executive chairman, especially for those successions involving outside appointments.

Originality/value: This paper extends the strategy and ability hypothesis by investigating the behaviour of equity volatility around CEO departures in case of prior under or outperformance along with the forced or voluntary nature of the turnover and provide new empirical evidence on the theories.

Keywords: CEO turnover; equity volatility; CEO ability; business strategy.

JEL Classification: G14, G30, G34, M51.

\section{INTRODUCTION}

A chief executive officer (CEO) turnover event in the life of a firm has particular implications for a firm's long-term survival, given all the business circumstances and economic conditions are looming in the horizon. A CEO's skills and preferences have a significant impact on a firm's business direction, which can differ from various types of CEOs. This study investigates a potentially significant consequence of CEO turnover in a firm: a change in equity-return volatility. Increased volatility could alter a firm's investment policy going forward through an increased cost of capital (Froot et al. (1991)) or through the decreased attractiveness of its equity as a medium for acquisitions or compensation (Baiman and Verrecchia (1995)). Further, it could affect the various agency relationships in the firm (Merton (1974)), for instance, by exacerbating conflicts between stockholders and bondholders and hindering the resolution of stockholdermanagement problems. It could also alter the internal decisions that rely on gleaning information from price changes. For example, high volatility costs might lead the board to choose a lower performance threshold as a trigger for replacing the management (Hallman \& Hartzell 2003).

*Address correspondence to this author at La Trobe University, Australia; E-mail: m.li@latrobe.edu.au
Prior research has documented the effects of stock return volatility on CEO turnovers. DeFond and Park (1999) find that the likelihood of CEO turnovers is positively associated with prior stock-return volatility in their regression analysis, but not in their univariate analysis. Bushman et al. (2010) find that the likelihood of forced CEO turnovers is increasing with idiosyncratic risk, but decreasing with systematic risk. Clayton et al. (2005) find that although both forced and voluntary turnovers increase equity volatility, post-event increases in volatility are higher for forced turnovers than for voluntary turnovers, and, compared to inside successions, outside successions are associated with higher volatility in the post-event period.

This study makes two contributions to the literature. First, it extends the strategy and ability hypothesis by investigating the behaviour of equity volatility around CEO departures in case of prior under or outperformance along with the forced or voluntary nature of the turnover. Second, this study provides empirical evidence showing that (1) the change in equity volatility is a positive function of previous underperformance, and (2) this change in equity volatility is more pronounced for forced turnovers, (3) retaining the old CEO in the firm as the executive chairman results in a lower change in post-turnover equity volatility, and (4) this lower change in volatility is larger if the new CEO is from outside the firm. Overall, this study provides evidence that the relationship between changes in volatility and CEO turnovers does 
not monotonically increase per se, but is a function of various turnover-specific variables that affect this association.

The remainder of this study is organised as follow: Section 2 provides the literature review and hypothesis development. Section 3 explains the sample, data, and methodology. Sections 4 and 5 present the empirical findings, and section 6 concludes.

\section{LITERATURE REVIEW AND HYPOTHESIS DE- VELOPMENT}

DeFond and Park (1999) find that although the likelihood of CEO turnovers is positively associated with prior stock return volatility. Similar findings are also documented in other studies, such as that of Hazarika et al. (2012), who explores the effect of earnings management on CEO turnovers. Peters and Wagner (2014) also find their results consistent with those of DeFond and Park (1999) and Hazarika et al. (2012). Bushman et al. (2010) directly explore the connection between firm performance risk and the likelihood of CEO turnovers. They find that the likelihood of CEO turnovers increases with idiosyncratic risk and decreases with systematic risk. Clayton et al. (2005) explore the subsequent consequences of CEO turnover about future equity volatility. Consistent with the strategy and ability hypotheses, they find that both forced and voluntary turnovers increase equity volatility, but that post-event increases in volatility are more substantial for forced turnovers than for voluntary turnovers.

Forced turnovers are ideally associated with significant changes in business strategies. As opposed to forced management changes, voluntary CEO turnover is not initiated by the BOD, which does not necessarily indicate that a change in strategies is imminent. The strategy during the new CEO tenure may stay the same or may change according to the skill sets of the new CEO and other changing market-wide variables. Moreover, when a change in strategy is needed, and the current CEO is close to the retirement age, the BOD might prefer to wait for retirement as it finds in this situation an opportunity to change the current strategy without rattling the succession process while minimising the financial cost associated with the change in management.

Denis and Denis (1995) and Huson et al. (2004) find significant changes in the operating variables ${ }^{1}$ following management changes; these changes are more pronounced in forced turnovers than in voluntary ones, suggesting that how a firm is managed has been changed drastically in forced departures as compared with voluntary departures. Clayton et al. (2005) relate the strategy hypothesis to the explanation of the change in volatility, following a top management change. The strategy hypothesis explains any increase in volatility following management changes as the result of increased uncertainty regarding the nature of the strategy that could be implemented by the new CEO. However, this hypothesis could not capture, in its current form, the behaviour of equity volatility around CEO departures in case of prior under or outperformance along with the forced or voluntary nature of the turnover. For example, it is doubtful that the departure of

${ }^{1}$ Examples include total assets, capital expenditure, and the number of employees. an outperforming CEO results from the need to have a change in strategy, as the current strategy provides superior returns for the shareholders. This doubt should apply whether the turnover is forced or voluntary because even when the turnover is voluntary, the successor is very unlikely to materially deviate from the current rewarding strategy of the departed CEO.

Murphy and Zimmerman (1993) find strong evidence that the change in operating variables such as $R \& D$, advertising, capital expenditure, and accounting accruals surrounding CEO turnovers occurs mainly because of poor past performance. Jenter and Lewellen (2017) introduced the concept of performance-induced CEO turnover and argue that preturnover performance is an important variable affecting CEO turnover and subsequent corporate events. According to this line of reasoning, this study expects that equity volatility would only increase if the performance during the departed CEO's tenure is weak as a result of a possible change in the firm's business strategy. However, there should be no increase in equity volatility following the departure of an outperforming CEO as no change in strategy is expected. In this sense, the first hypothesis is as follows:

H1: Replacing an underperforming CEO would result in a higher change in equity volatility than replacing an outperforming CEO.

Since the change in business strategy is more pronounced for forced turnovers than for voluntary turnovers ${ }^{2}$, this study expects that the forced nature of the turnover would result in a more significant effect on the change in equity volatility for underperforming CEOs.

H2: The positive association between a change in equity volatility and past poor performance should be stronger for forced CEO turnovers.

Learning model settings of MacDonald (1982), Murphy (1986), Gibbons and Murphy (1991), and Pan et al. (2014), among many others, highlight the effect of new information on agents' beliefs and behaviours. The ability hypothesis suggests that shareholders are virtually fully aware of the ability of the old (departing) CEO as they have all the necessary time to collect information about his skills and expertise during his tenure. Clayton et al. (2005) and Pan et al. (2014) find empirical evidence for the ability hypothesis in their studies. Accordingly, if the executive who relinquished the CEO title remained in the firm under a new equivalent or higher executive position, the problem of information asymmetry that the ability hypothesis posits can be mitigated by having this particular transition of leadership. The only executive position that can be equivalent to or higher than the CEO's position is that of the executive chairman. Moreover, being a chairman with executive powers would allow him to become extremely involved in the daily business operations and perform tasks that are the responsibility of a CEO. Accordingly, the executive chairman's post is one that is separate from a CEO's post. However, he can function as a CEO and even have a higher authority than a CEO. Hence, the third hypothesis is stated as follows:

\footnotetext{
${ }^{2}$ See Denis and Denis (1995) and Huson et al. (2004).
} 
H3: The change in equity volatility would be smaller when the old CEO stays on as an executive chairman in the firm.

$\mathrm{H} 3$ posits that retaining the old $\mathrm{CEO}$ as the executive chairman would substantially mitigate the high uncertainty associated with both types of successions. Moreover, since the ability of an outsider successor is lesser-known to investors than that of an insider successor, having the old CEO stay as executive chairman would be more valuable, in terms of mitigating the uncertainty associated with the appointment of a new CEO, in case of outside succession. Accordingly, the fourth hypothesis is proposed as follows:

H4: The negative relationship between the change in equity volatility and having the former CEO as the executive chairman would be stronger for outside successions.

\section{SAMPLE, DATA, AND METHODOLOGY}

The sample in this study includes CEO turnovers for firms belonging to the S\&P 1500 Index for the period from 2003 to 2012. That period experienced corporate governance reforms following the passage in 2002 of the Sarbanes-Oxley Act (SOX) that led to intense monitoring by the boards and the financial press. Data on CEO changes in those firms were collected during 2003-2012 or until the firms were delisted from the stock exchange. Arguably, the S\&P 1500 Index can be viewed as a good representative of the market as it includes companies of all sizes and industries. Most of the studies in the literature choose to examine CEO turnovers of the largest 500 companies, just because the data on these firms are easily accessible from articles and because they are always in the media spotlight. As the articles for most of the turnovers in the S\&P 400 and S\&P 600 companies are obtained for this study, any size bias issue has been minimised to the lowest possible level. After making adjustments to CEO turnovers associated with mergers and acquisitions, takeovers, and spinoffs, the final sample includes 735 CEO turnovers, which can be considered significant as compared to those used in event studies on CEO turnovers.

We extract the sample data from Execucompustat, Factiva, Compustat, and CRSP databases. Data on the top executives of these firms are obtained from Execucompustat, which provides information on the date an executive was appointed, the date he left the office, and his age, title, and name. This study uses Factiva to acquire all the articles dealing with CEO turnovers. The exact announcement date of the event, and the exact announcement date and the nature of the succession are obtained through the analysis of the articles for each of the CEO turnovers. Based on the work of Denis and Denis (1995) and Parrino (1997), this study takes into consideration specific characteristics that make the turnover most likely to be forced. When the articles state that the CEO is forced out or ousted, the turnover is classified as forced. When the articles state that the CEO is retiring, this study classifies the turnover as voluntary if the CEO is over 60 years old. This study further investigates those cases where the CEO is less than 60 years old, and the succession occurs less than six months after the departure announcement. This study classifies the turnover as forced if it satisfies both of the following conditions: (1) the CEO does not stay in the company in another position or until a successor is identified, and (2) does not find a comparable position in another company or start a new business. The same conditions are applied when the articles state that the CEO resigned, left by agreement with the board, or left to pursue other interests.

Cumulative abnormal returns (CARs) are used to classify a $\mathrm{CEO}$ as outperforming or underperforming. If a firm's market (or industry) adjusted cumulative monthly abnormal stock returns in the three years leading to a change in management is positive, the departing CEO is classified as outperforming; otherwise, the CEO is classified as underperforming. Following Ertugrul \& Krishnan (2011), prior stock returns are used for the primary classification of outperforming and underperforming CEOs because these returns arguably reflect information about the future cash flow of the firm, which is the main factor the BOD takes into consideration when deciding the top leader. The articles extracted from Factiva are used to identify a lack of succession planning in CEO turnovers. When the articles related to the announcement of the departure of the incumbent CEO state the name of the successor, this succession is classified as 'permanent'. When the articles state that an interim or acting CEO is appointed, this type of succession is classified as 'interim'. The incoming CEO is classified as an insider or outsider, depending on the articles related to the announcement of the successor.

The dependent variable is the volatility ratio measured as the $\log$-ratio of post-event to pre-event standard deviations. As in the study of Clayton et al. (2005), in order to lessen announcement effects and to test for persistence in volatility changes, the standard deviation of daily returns in year $t-2$ to the event is used as the base level or denominator in the ratio. A volatility ratio is then calculated for each of the three years after the turnover. Accordingly, the model specification is as follows:

$\operatorname{In} \frac{\text { volatlitu }_{t+n}}{\text { volatlitu }_{t+2}}=\beta_{0}+\beta_{1}$ underperformed $+\beta_{2}$ forced $+\beta_{3}$ underperformed.forced

$+\beta_{4}$ stay edas executive chair $+\beta_{5}$ outsider $+\beta_{6}$ stay ed.ousider + control $+\varepsilon_{t}$

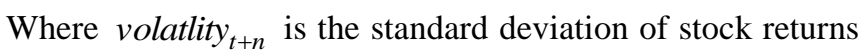
in the year $\mathrm{n}$ following the CEO turnover, with $\mathrm{n}$ taking the values of 1,2 , and 3 , and volatlity $_{t+2}$ is the standard deviation of stock returns in the year $\mathrm{t}-2$ to the turnover. Underperformed is a dummy variable equal to 1 if the monthly CARs adjusted for a benchmark performance in the three years leading to the turnover are negative, and 0 otherwise. This study uses two benchmarks for classification: (1) the return of the CRSP index as a proxy for market return and (2) the returns on Fama-French's 48 portfolios based on industry classification. Forced is a dummy variable that equals 1 if the CEO was forced out of the firm, and 0 otherwise; underperformed.forced is an interaction term referring to CEOs that outperformed the market and got ousted; outsider is an indicator variable that takes the value of 1 if the successor CEO is from outside the firm, and 0 otherwise; stayed as executive chair is a dummy variable equal to 1 if the departed CEO stayed in the company as executive chairman, and 0 otherwise; the interaction term between the last two variables stayed.outsider is included in the model. 
Control variables are constructed in the same spirit as that of Clayton et al. (2005). The specification controls for the market volatility are measured in the same manner as the volatility ratio constructed above. The CRSP value-weighted returns are used as a proxy for the market return, while the preturnover operating measure of performance or return on equity (ROE) is included to control for the signalling. Also, this study controls for size, and the market-to-book ratio is included as a proxy for growth opportunities in order to control for a possible cross-sectional relationship between volatility change and growth firms. Moreover, the regression models include a dummy variable for management changes preceded by an interim CEO period to observe whether employing a period of time to choose a permanent successor lessens the uncertainty regarding his ability, as boards normally take up to a few months to evaluate the ability of the new leader and determine whether he fits in with the firm's culture and the current business situation (Charan 2005). Moreover, interim successions represent a period of crisis manifested by high uncertainty about the future paths of firms (Ballinger \& Marcel 2010), and therefore, the appointment of a permanent successor could help lessen this uncertainty.

This study also constructs a measure of idiosyncratic volatility as the log ratio of post-event to pre-event using residuals from the Fama-French three-factor model. For each stock, the daily excess returns are regressed over returns on the following three portfolios:

$\mathrm{r}_{\mathrm{it}}=\alpha_{\mathrm{i}}+\beta_{\mathrm{i}} \mathrm{MKT}_{\mathrm{t}}+\beta_{\mathrm{i}} \mathrm{SMB}_{\mathrm{t}}+\beta_{\mathrm{i}} \mathrm{HML}_{\mathrm{t}}+\varepsilon_{\mathrm{it}}(2)$

The square root of the time series of these squared residuals is used to construct the measure of average idiosyncratic risk. Idiosyncratic volatility is defined as the measure of idiosyncratic risk computed from the three-factor model's residuals as follows: idiosyncratic volatility $=\sqrt{\frac{1}{N t} \sum(\text { sit })^{2}}$. Then, the volatility ratio is computed as the log-ratio of postevent to pre-event idiosyncratic volatility.

\section{EVIDENCE: VOLATILITY ACROSS CEO TURNO- VERS}

\subsection{Descriptive Statistics}

Table 1 presents the descriptive statistics and univariate analysis for different types of turnovers and successions. Volatility is defined as the standard deviation of daily stock returns over 250 days. The volatility for the full sample and the two subsamples, namely, forced and voluntary CEO turnovers, are reported. Firms that experience forced turnovers seem to be more volatile than those that experience voluntary turnovers over the pre- and post-event years. The change in volatility is positive and significant for the full sample in the two years following the turnover. However, for the forced turnover subsample, volatility seems to increase in the first and the second year post-event significantly. On the other hand, the voluntary turnover subsample does not experience any significant change in volatility as a result of CEO turnovers.
Table 1 also reports the volatility of turnovers that outperformed and underperformed the market in the three years leading to the event. Relative to the pre-turnover period, the outperformance subsample shows a decreasing trend in volatility, whereas the underperformance subsample exhibits an increasing trend. Volatility is higher post turnovers for firms whose CEOs have underperformed the market than for those whose CEOs outperformed the market. The one-, two-, and three-year changes in volatility are negative and significant for the outperformance subsample, whereas they are positive and significant for the underperformance sample. Moreover, departed CEOs who stay on in the firm as executive chairs help decrease volatility during the first year of the new CEO's tenure.

Table 2 reports the change in the growth rate of assets, the number of employees, capital expenditure, and net sales around under- and outperforming CEO turnovers. It can be seen that there is a substantial change in the growth rate of those variables for the underperforming sample in the postturnover period compared with the pre-turnover period; on the other hand, the change in those variables is not significant for the outperforming sample. The results presented in Table 2 support our argument that there are substantial changes in the way firms are managed, ${ }^{3}$ following the departure of underperforming CEOs.

Table 2 also reports the volatility change for turnovers preceded by the interim period and for CEO turnovers with outside succession. Both subsamples appear to experience an increase in volatility in the year following the turnover relative to the base year; however, the change in volatility is not significant for both subsamples. The volatility for the outside appointment subsample shares the same behaviour as the interim subsample, which is expected given that most firms that employ an interim period end up hiring an outsider.

Fig. (1) plots the standard deviation of daily returns computed quarterly for the 16 quarters or four years around the CEO turnover event. The most interesting aspect of Figure 1 is the pattern of volatility in the eight quarters following the event; for most types of turnovers (excluding the outperformance subsample), the volatility seems to be decreasing from the first quarter to the eighth quarter after the event, indicating decreasing volatility with the tenure of the new CEO. The result is consistent with the ability hypothesis and the learning process stating that the calibre of the new CEO becomes more precisely known over his tenure, which lowers equity volatility as a result of a decrease in uncertainty when reacting to the news.

Table 3 reports the summary statistics for annualised volatility patterns around the event of forced, voluntary, outperforming, and underperforming CEO turnovers. This table focuses on the change in overall risk components of stock returns around CEO turnovers. The results presented in panel A of Table $\mathbf{3}$ are similar to those presented in Table $\mathbf{1}$; the post-event volatility is higher compared to the pre-event period for the full sample as well as for the forced and

${ }^{3}$ The change in the growth rate of those variables that we plot is in line with the findings of Murphy and Zimmerman (1993). 
Table 1. Standard Deviation of Returns around CEO Turnover.

Volatility is defined as the standard deviation of daily stock returns over a 250 days or one year and reported in $\%$. $t-/+n$ refers to the year in time relative to the turnover event; for example, $t+1$ refers to the period of 250 days following the turnover, $t+2$ refers the period between 251 and 500 days following the turnover event and so on. Forced refer to CEO that got forced out of the position and voluntary refer to CEO that voluntary left their position. Underperformed (outperformed) refer to management changes with the three-year pre-turnover CARs are lower (higher) than that of the industry. Industry is defined according to Fama-French 48 industry classification. Stayed ex. Chair include turnovers with departed CEOs remain in the firm as an executive chairman of the board. Outsider sample is defined as a turnover involving a successor CEO from outside the firm. Interim is defined as a turnover when an interim CEO manage the firm until a permanent successor takes office. The standard deviation of market return is computed using the CRSP value-weighted index. Also presented are t-statistics and Wilcoxon rank-sum $\mathrm{Z}$ statistics for differences in means and median SD respectively. $* * *, * *, *$ represent significance at the $1 \%, 5 \%$, and $10 \%$ level respectively.

\begin{tabular}{|c|c|c|c|c|c|c|}
\hline \multicolumn{7}{|c|}{ Pre and Post CEO Turnovers Mean and Median SD of Returns } \\
\hline & \multirow[b]{2}{*}{$\mathbf{N}$} & \multirow{2}{*}{$\begin{array}{c}\text { Pre-turnovers } \\
t-2\end{array}$} & \multicolumn{4}{|c|}{ Post-turnover } \\
\hline & & & \multicolumn{2}{|c|}{$t+1$} & $t+2$ & $\mathbf{t + 3}$ \\
\hline \multirow[t]{2}{*}{ Full sample } & 721 & 2.40 & \multicolumn{2}{|c|}{2.49} & 2.47 & 2.41 \\
\hline & & [2.15] & \multicolumn{2}{|c|}{ [2.15] } & [2.07] & [2.08] \\
\hline \multirow[t]{2}{*}{ Forced } & 184 & 2.60 & \multicolumn{2}{|c|}{2.81} & 2.77 & 2.64 \\
\hline & & {$[2.33]$} & \multicolumn{2}{|c|}{$[2.34]$} & [2.40] & [2.40] \\
\hline \multirow[t]{2}{*}{ Voluntary } & 537 & 2.33 & \multicolumn{2}{|c|}{2.38} & 2.36 & 2.33 \\
\hline & & {$[2.10]$} & \multicolumn{2}{|c|}{$[2.07]$} & {$[2.01]$} & {$[2.03]$} \\
\hline \multirow[t]{2}{*}{ Outperformed } & 412 & 2.47 & \multicolumn{2}{|c|}{2.24} & 2.25 & 2.29 \\
\hline & & {$[2.17]$} & \multicolumn{2}{|c|}{$[2.06]$} & {$[1.97]$} & {$[2.01]$} \\
\hline \multirow[t]{2}{*}{ Underperformed } & 309 & 2.32 & \multicolumn{2}{|c|}{2.82} & 2.77 & 2.58 \\
\hline & & [2.13] & \multicolumn{2}{|c|}{ [2.24] } & {$[2.30]$} & {$[2.24]$} \\
\hline \multirow[t]{2}{*}{ Stayed ex. chair } & 59 & 2.58 & \multicolumn{2}{|c|}{2.17} & 2.30 & 2.29 \\
\hline & & {$[2.23]$} & \multicolumn{2}{|c|}{$[2.08]$} & {$[2.02]$} & {$[2.14]$} \\
\hline \multirow[t]{2}{*}{ Outsider } & 190 & 2.56 & \multicolumn{2}{|c|}{2.80} & 2.60 & 2.69 \\
\hline & & {$[2.23]$} & \multicolumn{2}{|c|}{$[2.29]$} & {$[2.34]$} & {$[2.30]$} \\
\hline \multirow[t]{2}{*}{ interim } & 103 & 2.60 & \multicolumn{2}{|c|}{2.86} & 2.77 & 2.89 \\
\hline & & {$[2.24]$} & \multicolumn{2}{|c|}{ [2.43] } & {$[2.42]$} & {$[2.42]$} \\
\hline CRSP-index & 721 & 1.01 & & & 1.11 & 1.11 \\
\hline & & {$[0.84]$} & & & {$[0.89]$} & [1.02] \\
\hline & & of Difference bet & Pre- and Po: & urnover Samp & & \\
\hline & & $(t-2)$ & $(t+2)$ & $(t-2)$ & & \\
\hline & T-statistic & Wilcoxon-Z & T-statistic & Wilcoxon-Z & T-statistic & Wilcoxon-Z \\
\hline Full sample & $1.74 *$ & 0.56 & $1.76^{*}$ & -0.52 & 0.75 & -0.45 \\
\hline Forced & $2.04 * *$ & 0.39 & $2.33^{* *}$ & 0.79 & 1.58 & 1.23 \\
\hline Voluntary & 0.66 & -0.43 & 0.45 & -0.68 & -0.15 & -0.84 \\
\hline Outperformed & $-2.92 * * *$ & $-2.91 * * *$ & $-2.63 * * *$ & $-2.85 * * *$ & $-1.86^{*}$ & $-2.49 * *$ \\
\hline Underperformed & $4.18^{* * * *}$ & $2.15^{* *}$ & $3.95 * * *$ & $2.02 * *$ & $2.77 * * *$ & $1.93^{*}$ \\
\hline Stayed ex. Chair & $-1.94 *$ & $-1.87^{*}$ & -1.59 & -1.37 & -1.34 & -1.34 \\
\hline outsider & 1.47 & 1.22 & 0.35 & 0.05 & 0.56 & 0.32 \\
\hline interim & 1.12 & 1.18 & 0.91 & 0.34 & 1.08 & 0.55 \\
\hline CRSP & $2.65^{* * *}$ & $2.34 * *$ & $4.08 * * *$ & $3.67 * * *$ & $4.33 * * *$ & $4.05^{* * * *}$ \\
\hline
\end{tabular}


Table 2. Pre- and Post-Turnover Average Changes in Operating Variables.

This table reports the average changes in firms' operations around CEO turnovers for the under- and outperformance samples. Underperformance (outperformance) refers to management changes with the three-year pre-turnover CARs are lower (higher) than that of the industry. Operating variables includes total assets, number of employees, capital expenditures, and net sales. The 2-year average growth rates of those variables are presented for the two years pre-turnover and two years post-turnover. $* * *$ indicate significance at the $1 \%$ level.

\begin{tabular}{|c|c|c|c|c|c|c|}
\hline & \multicolumn{3}{|c|}{ Underperformance } & \multicolumn{2}{c|}{ Outperformance } \\
\hline & Pre-turnover & Post-turnover & $\begin{array}{c}\text { T-statistics For } \\
\text { difference }\end{array}$ & Pre-turnover & Post-turnover & $\begin{array}{c}\text { T-statistics For } \\
\text { difference }\end{array}$ \\
\hline$\% \Delta$ Assets & $6.65 \%$ & $0.41 \%$ & $-6.62 * * *$ & $7.23 \%$ & $8.17 \%$ & 0.69 \\
\hline$\% \Delta$ Employees & $5.50 \%$ & $-8.41 \%$ & $-5.36 * * *$ & $9.64 \%$ & $5.28 \%$ & -1.54 \\
\hline$\% \Delta$ Cap. exp. & $2.45 \%$ & $-3.11 \%$ & $-5.78^{* * * *}$ & $1.95 \%$ & $3.77 \%$ & 7.27 \\
\hline$\% \Delta$ Sales & $6.09 \%$ & $1.76 \%$ & $-3.49^{* * * *}$ & $7.08 \%$ & $7.75 \%$ & 0.45 \\
\hline
\end{tabular}
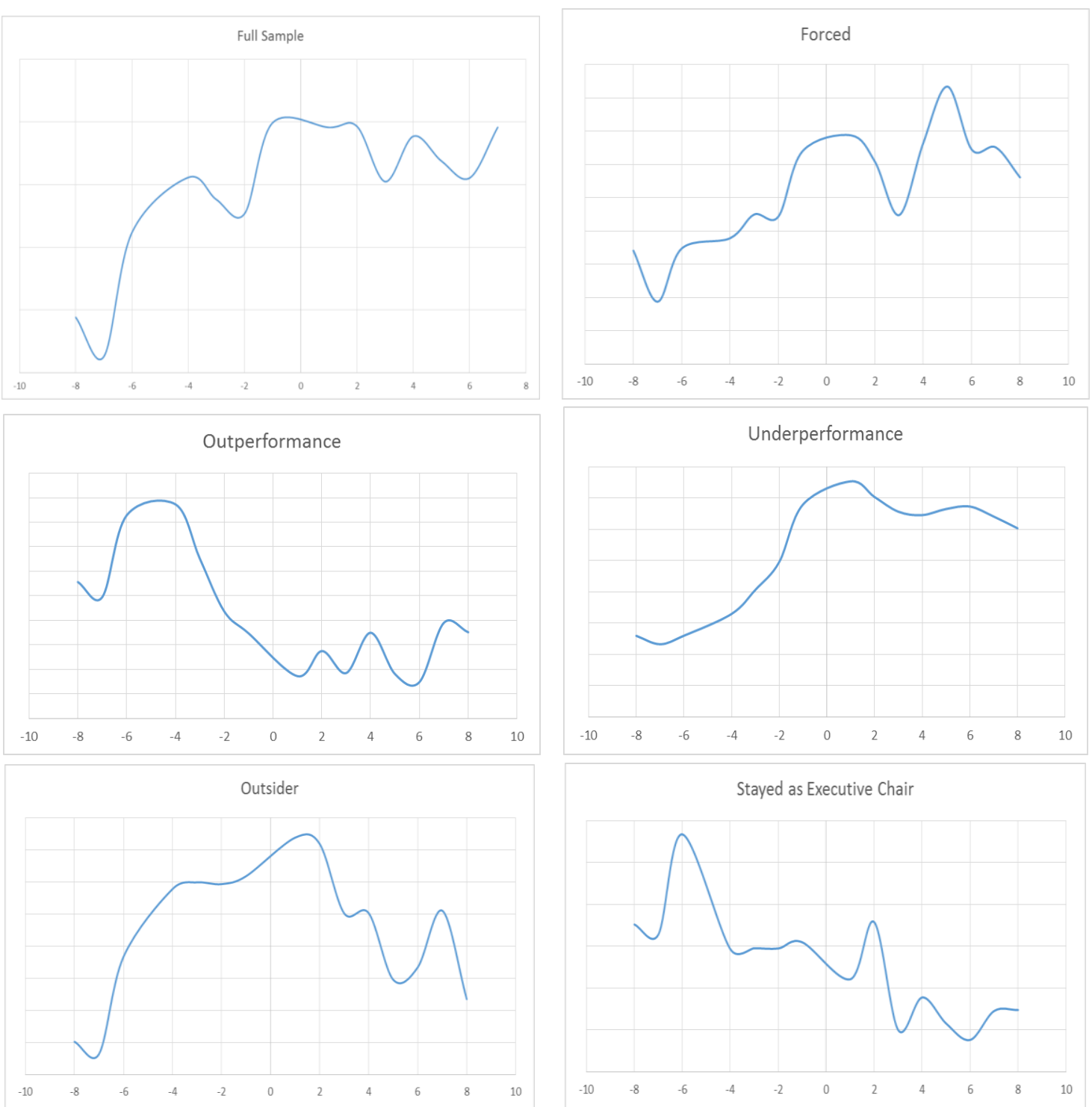

Fig. (1). Volatility around CEO Turnovers.

This figure plots the standard deviation of returns for the full turnover sample and for 5 CEO turnovers subsamples: forced, outperformance, underperformance, outsider, and stayed as executive chair. The standard deviation of daily stock returns is computed on a quarterly basis over 16 quarters surrounding CEO turnover events, with a quarter is defined as 63 trading days. 0 on the horizontal axis present the quarter of management change. 
Table 3. Annualised Volatility Before and After CEO Turnover.

This table reports the mean and standard deviation of annualised volatility in \% for year- 2 to the turnover and for the two years following the turnover. Subsamples are the same as in table 1. Volatility is annualised by multiplying the standard deviation of daily returns by the square root of 250 . Mean differences between post event volatility and pre-event volatility is reported. ***, **, and * represent significance at the $1 \%, 5 \%$, and $10 \%$ level respectively.

\begin{tabular}{|c|c|c|c|c|c|c|}
\hline & \multicolumn{2}{|c|}{ Volatility (t-500, t-250) } & \multicolumn{2}{|c|}{ Volatility $(t+1, t+500)$} & \multicolumn{2}{|c|}{ Difference } \\
\hline & Mean & SD & Mean & SD & Mean & T-statistics \\
\hline Full sample & 37.95 & [19.54] & 40.83 & {$[25.10]$} & $2.88 * * *$ & 2.63 \\
\hline Voluntary & 36.89 & {$[16.93]$} & 38.28 & {$[20.73]$} & 1.39 & 1.21 \\
\hline Outperformed & 39.08 & [16.26] & 35.98 & [15.09] & $-3.01 * *$ & -2.56 \\
\hline Stayed ex. Chair & 41.60 & [20.08] & 36.63 & [16.66] & $-4.97 *$ & -1.72 \\
\hline CRSP & 15.74 & {$[7.49]$} & 17.97 & [8.14] & $2.22 * * *$ & 4.90 \\
\hline
\end{tabular}

\section{Table 4. Stock Return Volatility Regression Tests.}

Volatility ratio is the dependent variable measured as the log-ratio of post-event to pre-event volatility. Models 4, 5, and 6 analyse the change in equity volatility with the inclusion of interaction terms. Volatility is defined as the standard deviation of daily stock returns. Underperformed is a dummy variable equal to 1 if the 3 -year market-adjusted CARs before the turnover are negative and 0 otherwise. Forced is a dummy variable that takes the value of 1 if the CEO is forced out of the position. Stayed as executive chair is a dummy that equals 1 if the $\mathrm{CEO}$ relinquishing the post remained as executive chairman of the board. Interim is a dummy equals 1 if the new CEO takes the helm from an interim CEO. Outsider equals 1 if the successor if from outside the firm or has been with the firm for less than a year. Control variables include market volatility, which is computed in the same manner as the dependent variable using the CRSP value-weighted index. Market-tobook is the pre-turnover ME/BE ratio, pre-turnover ROE is the net income over book value of equity, and size is the natural logarithm of market equity. Robust t-values are reported in parentheses and ***,**, * represent significance at the $1 \%, 5 \%$ and $10 \%$ level respectively.

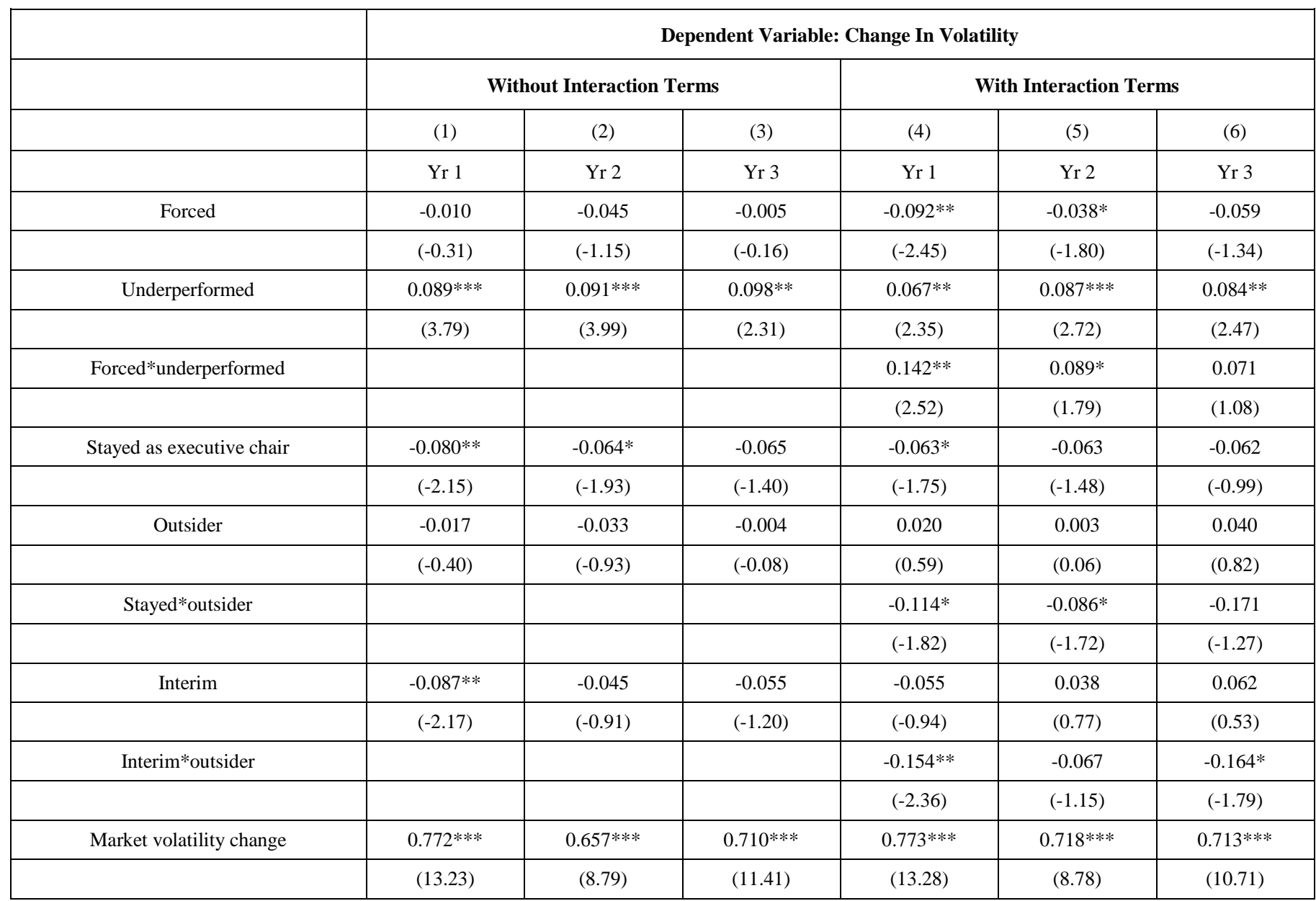




\begin{tabular}{|c|c|c|c|c|c|c|}
\hline Market-to-book & 0.001 & $0.001^{* *}$ & $0.001^{*}$ & 0.001 & $0.001^{* *}$ & $0.001^{*}$ \\
\hline & $(0.66)$ & $(2.53)$ & $(1.72)$ & $(0.90)$ & $(2.45)$ & $(1.65)$ \\
\hline Pre-turnover ROE & -0.004 & -0.001 & -0.006 & -0.014 & -0.001 & -0.007 \\
\hline & $(-0.66)$ & $(-0.02)$ & $(-1.39)$ & $(-0.52)$ & $(-0.04)$ & $(-1.47)$ \\
\hline Size & -0.011 & -0.022 & 0.016 & -0.010 & 0.003 & 0.016 \\
\hline & $(-1.38)$ & $(-0.23)$ & $(0.13)$ & $(-1.29)$ & $(0.28)$ & $-0.79)$ \\
\hline Intercept & -0.070 & -0.116 & $-0.232^{* *}$ & -0.042 & $(-0.116$ & $-0.234 * *$ \\
\hline Year and industry fixed effects & $(-1.02)$ & $(-1.34)$ & $(-2.45)$ & $(-0.65)$ & $(-1.43)$ & $(-2.60)$ \\
\hline Adj. R2 & yes & yes & yes & yes & yes & yes \\
\hline N & 713 & 0.70 & 0.68 & 0.64 & 0.71 & 0.68 \\
\hline
\end{tabular}

underperforming subsamples, but lower for the outperforming subsample.

\subsection{Regression Results}

Table 4 presents OLS regressions for changes in equity volatility on a set of independent variables. The level of change in equity volatility does not seem to be affected either by the forced nature of a CEO turnover or by the outside type of succession, as the coefficients on the forced and outside dummies are insignificant in all the three models. The negligible and insignificant coefficient of the outside dummy was not expected as outsiders tend to bring in new risky ideas for the company and are hired to implement significant changes in policies and strategies. The results are consistently significant for those CEOs that underperformed the market as the coefficient of the underperformed dummy is positive and significant in all the models. The departure of underperforming CEOs appears to bring about around 9\% more change in volatility post turnover than firms with outperforming CEOs. This finding supports $\mathrm{H} 1$, implying that CEOs that take the helm after a period of poor performance would more likely align their business strategy to lead to a higher equity volatility change compared with CEOs that assume the post after a period of good performance. It appears that the division of the sample into outperformance and underperformance has the most significant effect on the change in volatility over the period under investigation. Equity volatility of firms that fire an underperforming CEO appears to be higher compared to that of firms that fire an outperforming CEO.

Having the departed CEO stay on as an executive chairman along with the newly appointed chief executive seems to be a less volatile transition of leadership than solely assigning the ultimate executive power to the new CEO. This observation is manifested by the negative and significant coefficient of the stayed as executive chair dummy in the regression models of Table 4. This finding supports H3, implying that the information asymmetry regarding the ability of the newly appointed CEO is significantly mitigated when the old CEO is appointed as an executive chairman, compared with other types of successions. Moreover, the coefficient of the interim dummy is negative, but significant in model (1) alone, supporting that change in equity volatility is lesser in the first year following the change in management when the company takes time to evaluate the ability of the new successor; however, employing an interim period to select a permanent successor seems to lessen the uncertainty regarding the ability of outside CEO successions alone, as the coefficient of the interaction term Interim*outsider is negative and significant in models 4 and 6 . The inclusion of pre-turnover ROE can be seen as complementary to the primary independent variable underperformed, since both variables measure, to some extent, pre-turnover performance, where underperformed is based on stock performance, while pre-turnover ROE is a measure of accounting performance. The sign of the coefficient on the pre-turnover ROE is negative, which is consistent with the sign of the coefficient on underperformed, implying a negative relationship between change in equity and past performance; however, it is not statistically significant.

Forced turnovers tend to positively affect post-turnover equity volatility for those CEOs that underperformed in the preturnover period because the coefficient of the interaction term forced*underperformed is positive and significant in models 4 and 5. The coefficient of underperformed remains positive and significant in all the models after the inclusion of the interaction term; this finding suggests that the voluntary departure of CEOs that underperform the market would increase volatility post-departure, and this increase in volatility is even stronger if the departure is forced. This finding supports $\mathrm{H} 2$, which states that the positive association between change in equity volatility and past poor performance is stronger when the CEO turnover is forced.

The main explanation for the positive coefficient on the interaction term forced*underperformed in Table 4 is that the change in business strategy is more pronounced for forced turnovers compared to voluntary turnovers, according to the strategy hypothesis. However, a second potential plausible explanation exists. The signalling theory suggests that in certain circumstances, firing a CEO could provide a signal that a firm's outlook is worse than previously thought, which could increase the uncertainty surrounding the ability of the firm to implement its strategy in the future, leading to a greater change in volatility. However, a study by (Farah et al. 2015) has documented that firing an underperforming CEO is received as a positive signal by the market, as the market reaction to the announcement and the long-term market returns following the turnover are positive. Accordingly, the strategy hypothesis argument is more relevant for the expla- 
Table 5. Idiosyncratic Return Volatility Regression Tests.

Volatility is defined as the standard deviation of residuals obtained from the Fama-French three-factor model. Independent variables are the same as in table 4. Robust t-values are reported in parentheses and ***, **, * represent significance at the $1 \%, 5 \%$ and $10 \%$ level respectively.

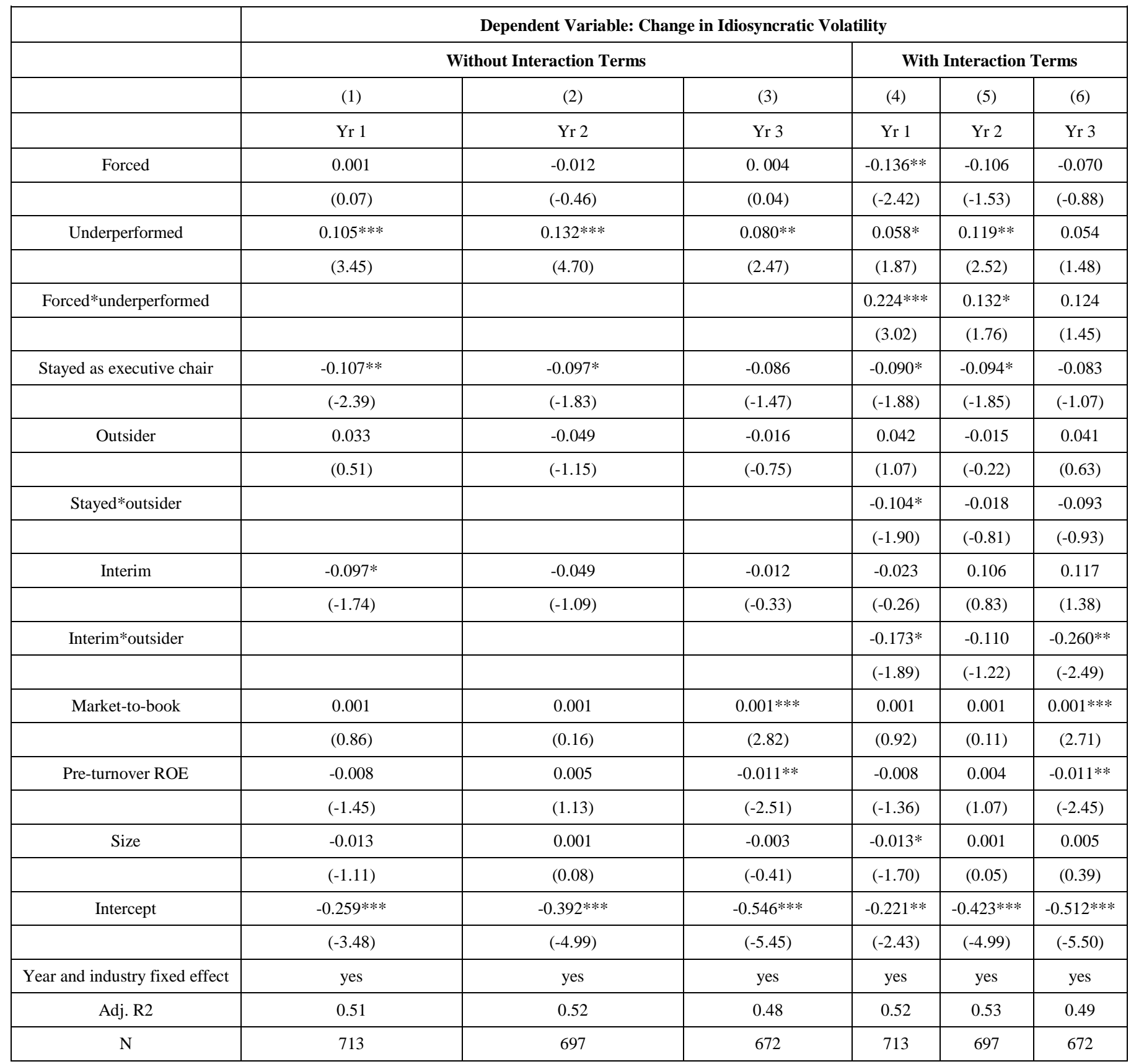

nation of the positive coefficient on forced*underperformed in our turnover sample.

Table 4 also reports the effect of the old CEO staying as executive chair with the appointment of an outsider successor on the change in volatility by including the interaction term stayed*outsider. The coefficient on this interaction term Stayed*outsider is negative and significant in models 4 and 5. Having the old CEO staying on as the executive chairman would result in around $11 \%$ less change in volatility for outside successions compared to inside successions in the first year when the new CEO takes office. The coefficient on stayed as executive chair variable remains negative and significant for the first year period following the turnover. This finding supports $\mathrm{H} 4$, implying that the negative relationship between the change in equity volatility and retaining the old $\mathrm{CEO}$ as the executive chairman would be stronger for outside successions.

Moreover, regression tests with the change in idiosyncratic volatility as the primary independent variable, are performed and presented in Table 5. Idiosyncratic volatility ratio is 
Table 6. Idiosyncratic Return Volatility Regression Tests with Alternative Benchmark for Performance.

Underperformed is a dummy variable equal 1 if the 3-year industry adjusted monthly CARs before the turnover are negative and 0 otherwise; we use the Fama-French 48 industry classification for matching. All other variables are as defined in table 4 . Robust t-values are reported in parentheses. $* * *, * *$ and $*$ indicate significance at the $1 \%, 5 \%$ and $10 \%$ levels respectively.

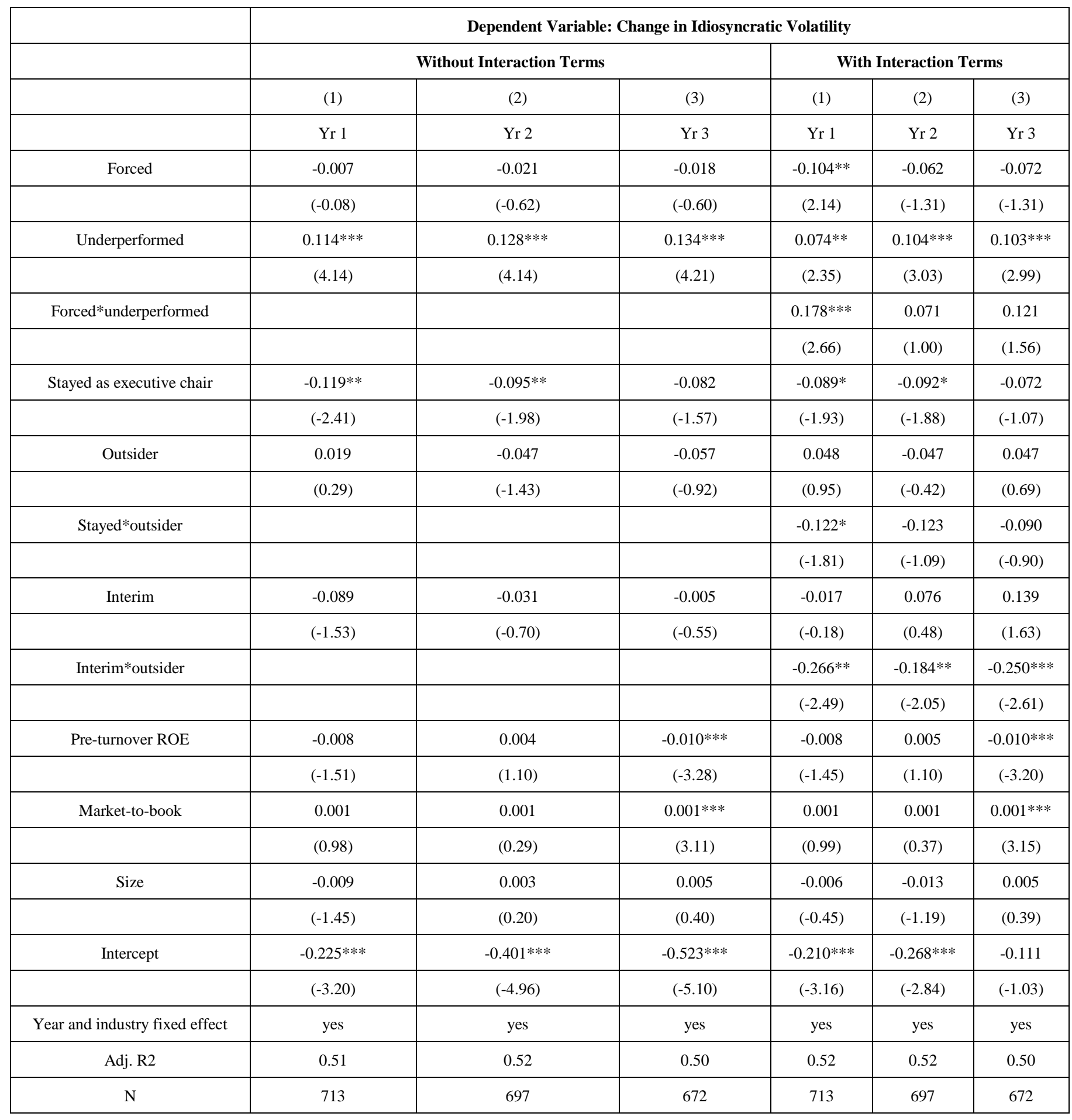

computed in a similar way to the stock return volatility but using the standard deviation of residuals obtained from the Fama-French three-factor model instead of the standard deviation of stock returns. The results presented in Table $\mathbf{5}$ are consistent, to some extent, with the results in Table 4 . The coefficients on underperformed and the interaction term forced*underperformed remain negative and significant; the coefficients on stayed as executive chair, and interim are negative and significant. Moreover, the coefficient on the interaction terms stayed*outsider and interim*outsider is negative and significant in the first year following the management change. Besides, this study uses the returns of 
Fama-French's 48 portfolios that are constructed on industry classification as a benchmark for the classification of underperformance and outperformance departures in Table $\mathbf{6}$ and finds the same qualitative results. The models in Table 6 use the standard deviation of the residual stock return of the Fama-French's three-factor model as a volatility measure.

\section{ROBUSTNESS CHECK}

Pan et al. (2014) document a convex relationship between volatility and tenure of new CEOs as a result of the market learning about CEO ability over time, reducing the uncertainty about management. This issue is explored using regression analysis with polynomial specifications; the results support the convexity of the relationship for the full CEO turnover sample However, when the full sample is divided based on past performance, the relationship between volatility and tenure remains significant for the underperformance sample in models, but completely loses its statistical significance for the outperformance sample. These results suggest that some endogenous factors affect the volatility-tenure relationship. One plausible explanation is that the market learns about the CEO's ability through the dynamicity of the business strategy very early in the CEO's tenure, which is more likely to happen as a result of his poor past performance during his previous tenure. The uncertainty regarding the ability of the new CEO is more dominant when he implements changes in business operations. This finding supports our argument that a change in the way the firm is managed has a substantial effect on equity volatility following management turnovers. ${ }^{4}$

The results suggest that turnover causes a change in volatility. But CEO turnover is a choice, and as such it could itself be caused by volatility or performance (or other nonobservable factors). To deal with this issue, we control for non-turnover related firm-specific characteristics by constructing two matching samples of firms based on pre-event return and volatility and including the change in volatility of the two control samples in the regression analysis. Further robust tests are implemented but not reported for space constraints. Quantile regressions with bootstrapped errors are performed to deal with normality and outliers. Volatility regression tests are performed using a volatility ratio with year minus one to the turnover as the base year. All of the robust tests support the conclusions drawn in this study.5

\section{CONCLUSION}

Since the change in stock-price volatility can have a significant impact on the firm's operations, and its management and stakeholders, this study seeks to explore and explain the volatility consequences of CEO turnovers. At the univariate analysis level, the study finds that the volatility increases in the two years post turnover for all turnover events and forced departure events. No statistically significant change in volatility is observed post turnover for the turnovers that involve outside successions at the univariate level. The increase in

\footnotetext{
${ }^{4}$ To save space, we don't report the result in this paper, however, the result will be available upon request.

${ }^{5}$ To save space, we don't report the result in this paper, however, the result will be available upon request
}

volatility for the forced turnovers and outside successions turns out to be insignificant in the multivariate analysis after controlling for changes in market volatility.

This study also documents strong evidence that turnovers involving the departure of underperforming CEOs increase volatility post turnover, especially if the turnover is forced. The change in business strategy following CEO turnover events is more noticeable when the performance during the tenure of the departed CEO is weak, and the scale of the change in the strategy is much larger for forced departures compared to voluntary departures. This study highlights an essential advantage of having the chairman of the board share executive powers; executives that leave their CEO posts for executive chairman posts substantially succeed in lessening the uncertainty regarding the ability of the newly appointed CEO, resulting in a decrease in equity volatility. This study also shows that having the old CEO staying on as executive chairman is more critical, in terms of moderating uncertainty when the successor is from outside the firm.

Overall, this study provides new evidence on the importance of CEO turnovers. While the previous studies have shown changes in shareholder wealth around the announcement of turnover, followed by changes in operations, this study documents a significant change in the volatility of the stockprice process around a change in firm leadership resulting from different types of turnovers and successions. The volatility changes that follow CEO turnovers may have a significant impact on the firm, and the board should plan a succession strategy and take into account the variables shown to have an effect on volatility.

\section{CONFLICT OF INTEREST STATEMENT}

The authors declare that they have no conflict of interest.

\section{REFERENCES}

Baiman, S., Verrecchia, R.E., 1995. Earnings and price-based compensation contracts in the presence of discretionary trading and incomplete contracting. Journal of Accounting and Economics 20, 93-121.

Ballinger, G.A., Marcel, J.J., 2010. The use of an interim CEO during succession episodes and firm performance. Strategic Management Journal 31, 262-283.

Bushman, R., Dai, Z., Wang, X., 2010. Risk and CEO turnover. Journal of Financial Economics 96, 381-398.

Charan, R., 2005. Ending the CEO succession crisis. Harvard business review 83, 72-81.

Clayton , M.C., Hartzell, J.C., Rosenberg, J., 2005. The Impact of CEO Turnover on Equity Volatility. The Journal of Business 78, 17791808.

DeFond, M.L., Park, C.W., 1999. The effect of competition on CEO turnover. Journal of Accounting and Economics 27, 35-56.

Denis, D.J., Denis, D.K., 1995. Performance changes following top management dismissals. The Journal of finance 50, 1029-1057.

Ertugrul, M, and Krishnan, K, 2011. Can CEO dismissals be proactive? Journal of Corporate Finance, 17, 134-151.

Froot, K.A., Perold, A.F., Stein, J.C., 1991. Shareholder trading practices and corporate investment horizons. National Bureau of Economic Research.

Gibbons, R., Murphy, K.J., 1991. Optimal incentive contracts in the presence of career concerns: Theory and evidence. National Bureau of Economic Research.

Hallman, G., Hartzell, J., 2003. The impact of the likelihood of turnover on executive compensation. University of Texas at Austin working paper. 
Hazarika, S., Karpoff, J.M., Nahata, R., 2012. Internal corporate governance, CEO turnover, and earnings management. Journal of Financial Economics 104, 44-69.

Huson, M.R., Malatesta, P.H., Parrino, R., 2004. Managerial succession and firm performance. Journal of Financial Economics 74, 237-275.

Jenter, Dirk and Lewellen, Katharina, Performance-Induced CEO Turnover (July 27, 2017). Available at SSRN: https://ssrn.com/abstract=1570635

MacDonald, G.M., 1982. A market equilibrium theory of job assignment and sequential accumulation of information. The American Economic Review 72, 1038-1055.

Merton, R.C., 1974. On the pricing of corporate debt: The risk structure of interest rates. The Journal of finance 29, 449-470.

Murphy, K.J., 1986. Incentives, learning, and compensation: A theoretical and empirical investigation of managerial labor contracts. The Rand Journal of Economics, 59-76.
Murphy, K.J., Zimmerman, J.L., 1993. Financial performance surrounding CEO turnover. Journal of Accounting and Economics 16, 273-315.

Farah, Paul and Li, (Michael) Hui and Nguyen, Lily, CEO Turnover: Transparency of Announcements and the Outperformance Puzzle (August 20, 2015)

Available at SSRN: https://ssrn.com/abstract=2647838 or http://dx.doi.org/10.2139/ssrn.2647838

Pan, Y., Wang, T.Y., Weisbach, M.S., 2014. Does Uncertainty about Management Affect Firms' Costs of Borrowing? National Bureau of Economic Research.

Parrino, R., 1997. CEO turnover and outside succession a cross-sectional analysis. Journal of Financial Economics 46, 165-197.

Peters, F.S., Wagner, A.F., 2014. The executive turnover risk premium. The Journal of Finance 69, 1529-1563.

Received: Jan 05, 2021

Copyright () 2020- All Rights Reserved

This is an open-access article. 